\title{
The Relative Research on Planning, Modelling, and Analysis of G+6 Residential Buildings with and without Multi-level Car Parking Facility
}

\author{
Sayan Ghar, Kushal Jain
}

\begin{abstract}
In India, normally the proposed buildings are either residential or commercial cum residential. Generally, the parking is provided in the basement of the buildings or open to the sky, based on the availability of space. But there are some cases due to the high cost of land, it is not possible to provide an open space parking facility. On the other hand, parking facilities are very critical in metropolitan cities like Mumbai, Kolkata, Chennai, Delhi, etc. Due to the high number of vehicles on the roads. In some places due to the non-availability of the parking, the people had to face issue in their day to day work and some times had to pay fine for illegal parking. In this project, the crisis of the parking facilities is kept in mind and relative research is done to check whether it can be adapted in the cities of India or not to minimize the issues. And also the analysis of structures is done to check the stability of the structures.
\end{abstract}

Keywords: G+6 Building, Multi-level Car Parking, Multi-storey, Modelling and Analysis, Relative Research, Hydraulic Lift.

\section{INTRODUCTION}

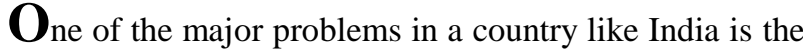
rapid increase in population, lack of spaces, especially in metropolitan cities. Due to the lack of land space and high cost, it is preferred to build multi-storied buildings. On the other hand, every year millions of cars and motorcycles are sold in India, causing parking issues, especially in metropolitan cities. The problem can be minimized by constructing multi-level car parking in a multi-storied residential building ${ }^{[1]}$. The multi-level car parking maximizes the utilization of space and maintains an easy traffic flow on the road. The main aim of constructing a multi-storied building is to ensure that the structure of the building is safe and economical against all loading conditions and prevent any type of failure. The centralized hydraulic lift is used in the multi-level car parking area for easy vertical transportation of the car from one level to another and preventing any confusion among the cars. The presence of a ramp and lift facility maintains the proper flow of traffic inside the parking zone. The building is planned in such a way that it maintains proper air circulation throughout the building.

Revised Manuscript Received on October 20, 2020.

* Correspondence Author

Sayan Ghar*, B.Tech (Civil Engineering) from SRM Institute of Science and Technology (SRM IST), Kattankulathur, Tamil Nadu, India.

Kushal Jain, working as a Designer And Site Engineer In A Reputed Construction Company in Chhattisgarh, India.

(C) The Authors. Published by Blue Eyes Intelligence Engineering and Sciences Publication (BEIESP). This is an open access article under the CC BY-NC-ND license (http://creativecommons.org/licenses/by-nc-nd/4.0/)
The building with a multi-level car parking facility is considered as Building I whereas the building without a multi-level car parking facility is considered as Building II.

\section{PLANNING AND LOAD CALCULATION}

A G+6 residential building with a multi-level car parking facility; till the second floor, is analyzed and results (moments and shear forces) are compared with another residential G+6 building with car parking on the ground floor. Table I shows the different parameters for the respective buildings as mentioned below. The analysis of both buildings is carried out in STAAD. Pro ${ }^{[2][3]}$. The planning of the building is based on NBC vol 1 and vol 2. These parameters mentioned below are used to carry out the planning and analysis of the structures.

Table I. Parameters for Planning (Site Description)

\begin{tabular}{|l|l|}
\hline \multicolumn{1}{|c|}{ Description } & \multicolumn{1}{c|}{ Details } \\
\hline Area of Land & 1327.14 sq.m \\
\hline Width of Road & $24.994 \mathrm{~m}$ \\
\hline $\begin{array}{l}\text { Permissible Floor Area } \\
\text { Ratio (FAR) }\end{array}$ & 3.0 \\
\hline $\begin{array}{l}\text { Permissible Ground } \\
\text { Coverage (50 \%) }\end{array}$ & 663.57 sq.m \\
\hline Permissible Covered Area & $1327.14 \times 3.0=3981.4$ sq.m \\
\hline Permissible Height & $1.5 \times(24.994+6)=46.5 \mathrm{~m}$ \\
\hline No. of Stories & G+6 (7 Storied) \\
\hline Each Floor Height & $2.9 \mathrm{~m}$ \\
\hline Total Proposed Height & $20.3 \mathrm{~m}$ \\
\hline Grade of Concrete & M30 \\
\hline Grade of Steel & $415 \mathrm{Grade}$ \\
\hline $\begin{array}{l}\text { Proposed Land Area } \\
\text { Coverage }\end{array}$ & $560 \mathrm{sq.m}(42.2 \%)$ \\
\hline Open to Sky & $767.138 \mathrm{sq.m} \mathrm{(57.8} \mathrm{\% )}$ \\
\hline Column Dimension & $600 \mathrm{~mm} \times 250 \mathrm{~mm}$ \\
\hline Beam Dimension & $250 \mathrm{~mm} \times 400 \mathrm{~mm}$ \\
\hline Overall Slab Thickness & $150 \mathrm{~mm}$ thick \\
\hline $\begin{array}{l}\text { No of Levels in } \\
\text { Multi-Storey Car Parking }\end{array}$ & $3\left(\mathrm{Ground}\right.$ to $\left.2^{\mathrm{nd}} \mathrm{floor}\right)$ \\
\hline
\end{tabular}

The floor height of the building is considered to be $2.9 \mathrm{~m}$. The total number of floors in the buildings is seven. Thus the total height is $20.3 \mathrm{~m}$ which is under the permissible height.

\section{Published By:}

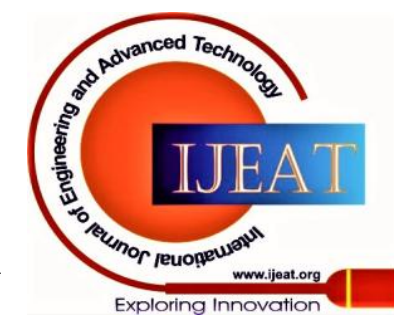




\section{The Relative Research on Planning, Modelling, and Analysis of G+6 Residential Buildings with and without Multi-level Car Parking Facility}

The dimension of the column is considered to be $600 \mathrm{~mm} \times$ $250 \mathrm{~mm}$. And the dimension of the beam is considered to be $250 \mathrm{~mm} \times 400 \mathrm{~mm}$. The overall slab thickness is considered as $150 \mathrm{~mm}$. The thickness of the slab can be varied from 150 $\mathrm{mm}$ to $175 \mathrm{~mm}$ depending on the increment of the variable load ${ }^{[4]}$. The Floor Area Ratio (F.A.R) is considered as 3.0. The above values (FAR, permissible ground coverage, etc) are based on the rules authorized by metropolitan authority. The values mentioned in Table II are based on IS 875 (Part - 1): 1987, which is the Code for Design of Dead Load (DL), and IS 875 (Part - 2): 1987, which is the Code for Design of Imposed Load (LL). And also the wind load is considered as $4 \mathrm{kN} / \mathrm{m}^{2}$, which is acting laterally on the buildings. The factor of safety (FOS) is considered as 1.5. The ultimate load (UL) is calculated as (Dead Load + Live Load + Floor Finish) $\times$ FOS

Table II. Detailed Load Calculation

\begin{tabular}{|l|l|}
\hline \multicolumn{2}{|c|}{ Load Calculation of Building I and Building II } \\
\hline Load Type & Value \\
\hline Dead Load (DL) & $3.75 \mathrm{kN} / \mathrm{m}^{2}$ \\
\hline Imposed Load (LL) & $2.5 \mathrm{kN} / \mathrm{m}^{2}$ \\
\hline Floor Finish & $0.6 \mathrm{kN} / \mathrm{m}^{2}$ \\
\hline Factor of Safety (FOS) & 1.5 \\
\hline Ultimate Load & $\mathbf{1 0 . 2 7 5} \mathbf{~ k N / m ^ { 2 }}$ \\
\hline
\end{tabular}

Fig 1. and Fig 2. represent the front elevation of building with multi-level car parking and building without multi-level car parking facility respectively.

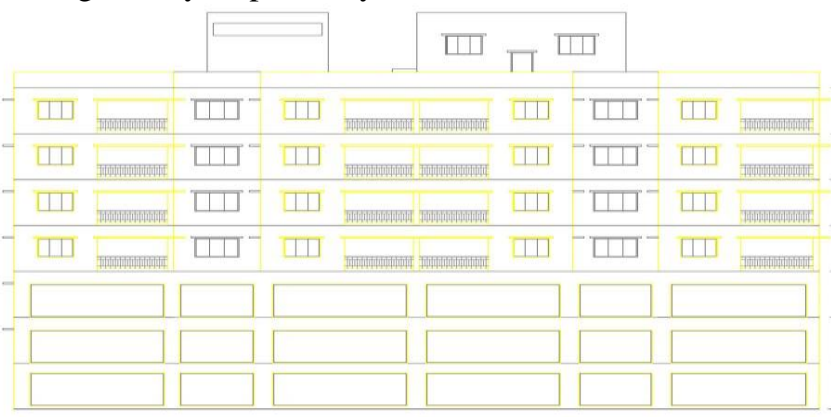

Fig 1. Front Elevation of Building with Multi-level Car Parking (Building I)

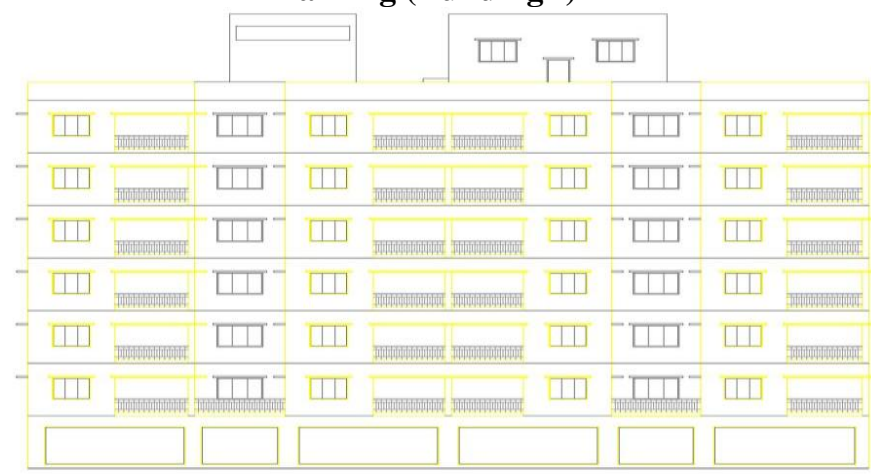

Fig 2. Front elevation of building without multi-level car parking (Building II)

The parking layout of the Multi-level car parking (Building I) is shown in Fig 3. In this figure, the $4 \mathrm{~m}$ wide passage is provided which is enough for two cars to pass by simultaneously ${ }^{[5]}$. There is a certain uniqueness that is followed in this parking - a) The ramp is provided for the cars to climb up the floors i.e from the ground to first or from first to second. B) The centralized hydraulic lift is for bringing the vehicles down to from any floor to the ground floor. i.e from second to ground or from first to ground. This type of uniqueness was possible to adapt to this type of building because of the less no. of apartments. This type of system is beneficial where the building is located in a very crowded place and it's not possible to get parking in that locality. The arrow determines the path to be followed by the cars while entering and exiting the multi-level car parking.

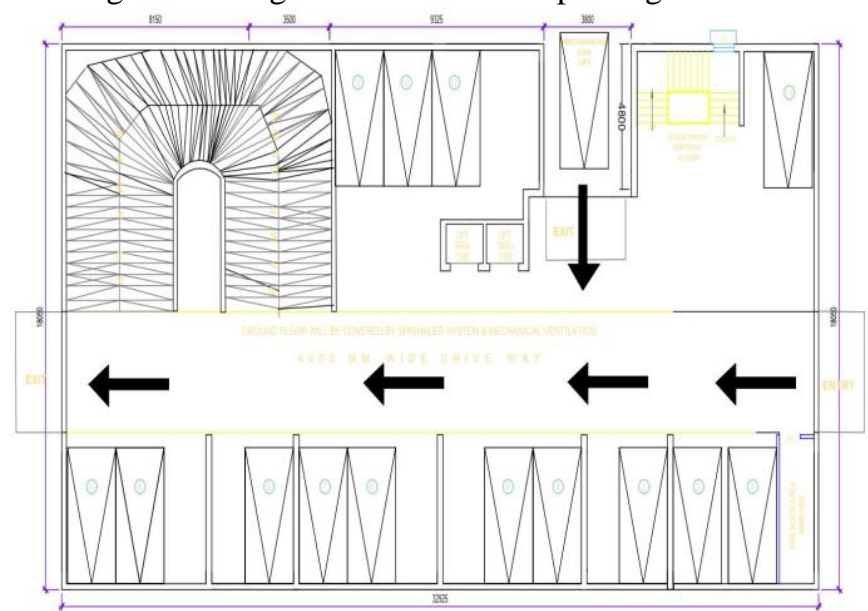

Fig 3. The layout of Multilevel Car Parking (Building I)

In Fig 4. the layout of the ground floor car parking of Building II is shown. In this layout, the provision for two passenger lift, staircase are also provided, similar to Fig 3. But there is no provision for a ramp or hydraulic car lift as this is a single floor (ground) car parking. Similarly, the arrow determines the path to be followed by the cars while entering and exiting the car parking. They are provided for each car parking is $12 \mathrm{sqm}$. The width of the passage is $4 \mathrm{~m}$.

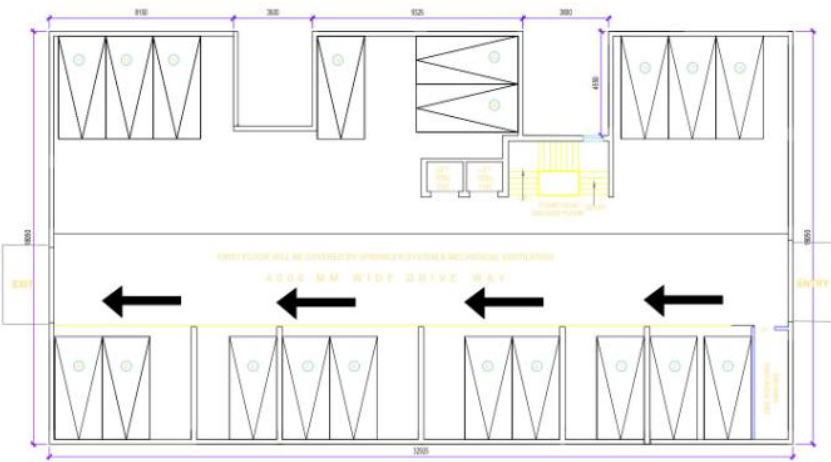

Fig 4. The layout of Ground Floor Car Parking (Building II)

\section{ANALYSIS AND RESULT}

The structural analysis of the $\mathrm{G}+6$ building with and without a multi-level car parking facility is done using STAAD Pro. The moments, shear forces, and deflections of the critical columns (Column I, Column II) and critical beams (Beam I, Beam II) of both the buildings are analyzed, studied, and compared. Both the buildings in the configuration have seven numbers of stories.

\section{Published By:}

Blue Eyes Intelligence Engineering and Sciences Publication

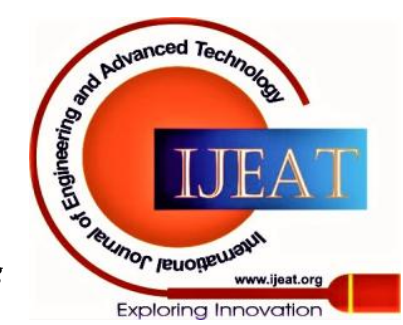


The elements are considered as critical because of the highest bending moment acting on that element (horizontal or vertical). During the analysis, the add beam method has been used in STAAD Pro ${ }^{[6]}$. to frame the structure. In Fig 5, the red portion shows the critical beam (Beam I) in Building I. The Bending Moment Diagram (BMD), Shear Force Diagram (SFD), and the Deflection Diagram of Beam I are shown in Fig 6. And the maximum values are further tabulated in Table III.

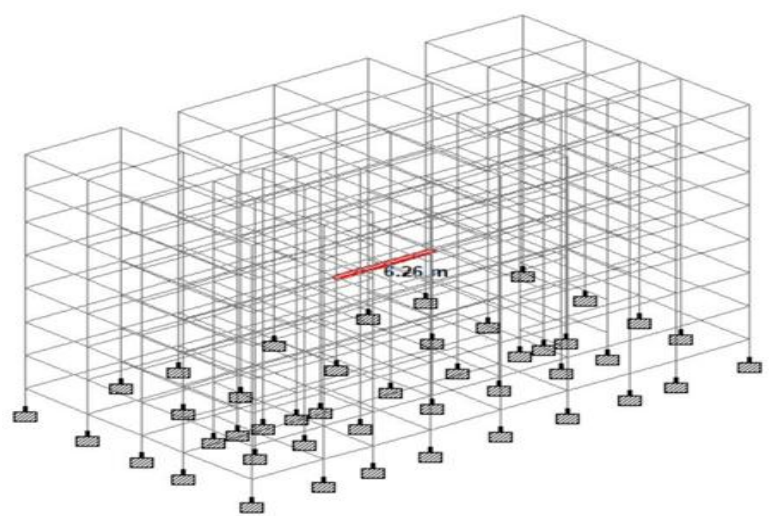

Fig 5. Red Portion shows the Beam I (Building I)

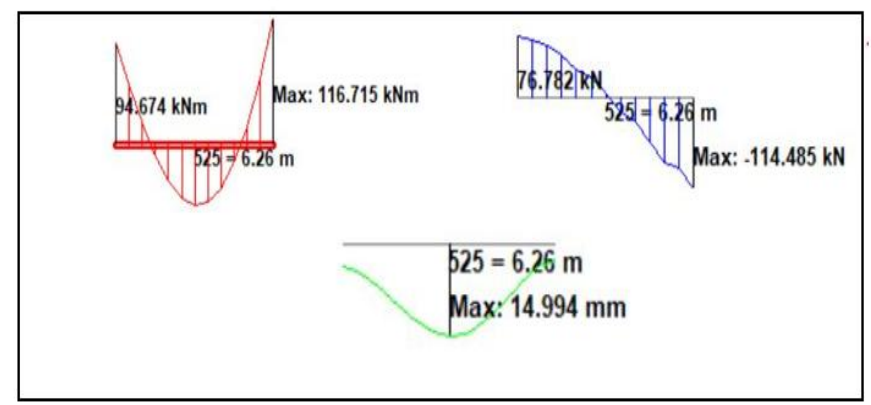

Fig 6. BMD, SFD, and Deflection Diagram of Beam I (Building I)

Table III. BM, SF, and Deflection of Beam I (Building I)

\begin{tabular}{||l|l|l||}
\hline S.NO. & DESCRIPTION & VALUES \\
\hline 1. & Maximum BM & $116.715 \mathrm{kNm}$ \\
\hline 2 & Maximum SF & $-114.485 \mathrm{kN}$ \\
\hline 3 & Maximum Deflection & $14.994 \mathrm{~mm}$ \\
\hline
\end{tabular}

In Fig 7, the red portion shows the critical column (Column I) in Building I. The Bending Moment Diagram, Shear Force Diagram, and the Deflection Diagram of Column I are shown in Fig 8. And the maximum values are further tabulated in Table IV.

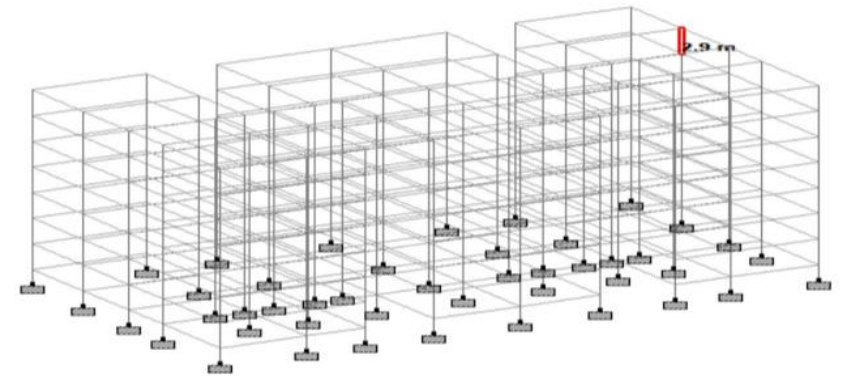

Fig 7. Red Portion shows the Column I (Building I)

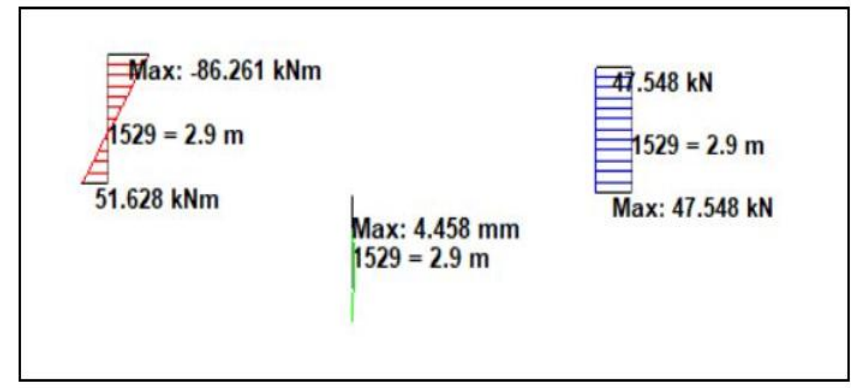

Fig 8. BMD, SFD, and Deflection Diagram of Column I (Building I)

Table IV. BM, SF, and Deflection of Column I (Building I)

\begin{tabular}{||l|l|l||}
\hline S.NO. & DESCRIPTION & VALUES \\
\hline 1. & Maximum BM & $-86.261 \mathrm{kNm}$ \\
\hline 2 & Maximum SF & $52.810 \mathrm{kN}$ \\
\hline 3 & Maximum Deflection & $2.90 \mathrm{~mm}$ \\
\hline
\end{tabular}

In Fig 9, the red portion shows the critical beam (Beam II) in Building II. The Bending Moment Diagram, Shear Force Diagram, and the Deflection Diagram of Beam II are shown in Fig 10. And the maximum values are further tabulated in Table $\mathrm{V}$. The values are to be further used for designing of Structural Elements (Slab, Beam, Column).

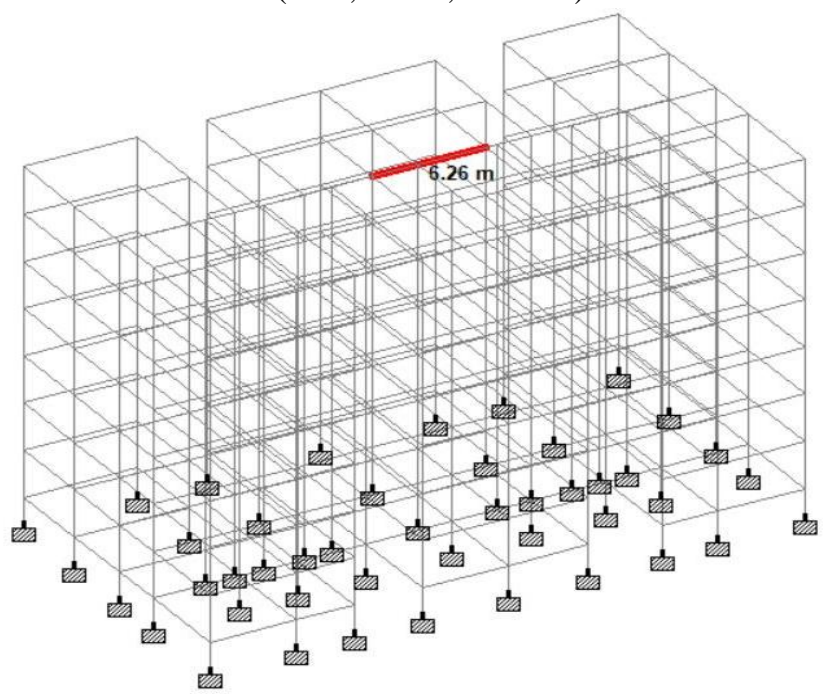

Fig 9. Red Portion shows the Beam II (Building II)

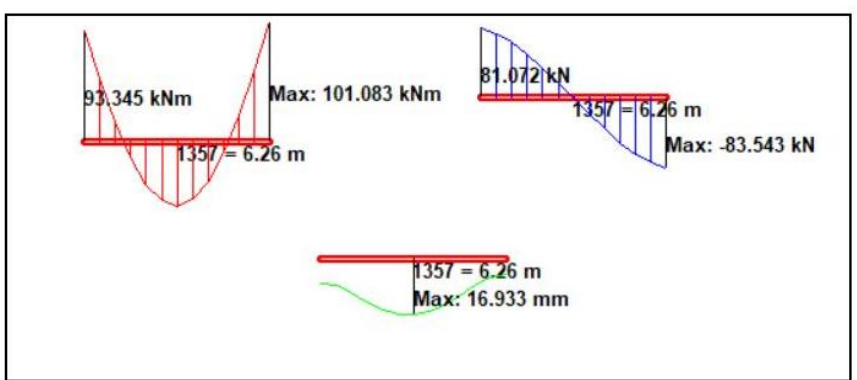

Fig 10. BMD, SFD, and Deflection Diagram of Beam II (Building II)

Published By:

Blue Eyes Intelligence Engineering

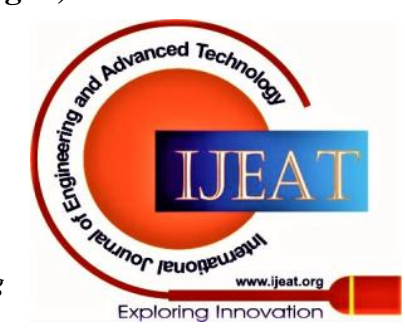


The Relative Research on Planning, Modelling, and Analysis of G+6 Residential Buildings with and without Multi-level Car Parking Facility

Table V. BM, SF, and Deflection of Beam II (Building II)

\begin{tabular}{||l|l|l|}
\hline \hline S.NO. & DESCRIPTION & VALUES \\
\hline 1. & Maximum BM & $101.083 \mathrm{kNm}$ \\
\hline 2 & Maximum SF & $-83.543 \mathrm{kN}$ \\
\hline 3 & Maximum Deflection & $16.933 \mathrm{~mm}$ \\
\hline
\end{tabular}

In Fig 11, the red portion shows the critical column (Column II) in Building II. The Bending Moment Diagram, Shear Force Diagram, and the Deflection Diagram of Column II are shown in Fig 12. And the maximum values are further tabulated in Table VI.

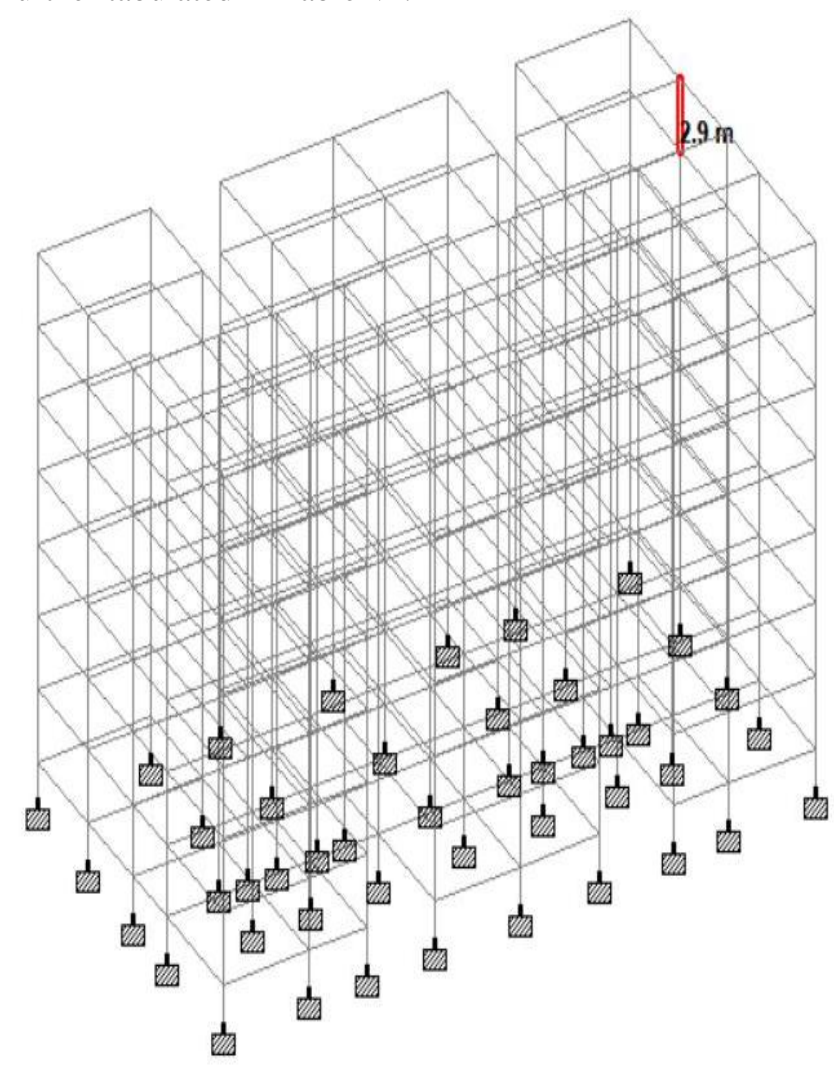

Fig 11. Red Portion shows the Column II (Building II)

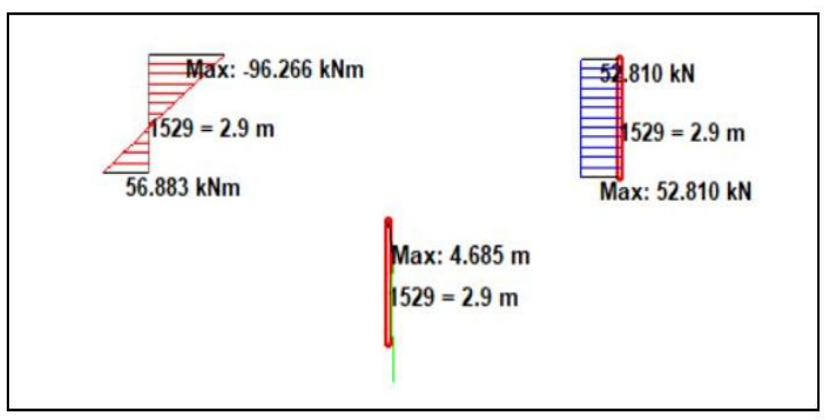

Fig 12. BMD, SFD, and Deflection Diagram of Column II (Building II)

Table VI. BM, SF, and Deflection of Column II (Building II)

\begin{tabular}{||l|l|l||}
\hline S.NO. & DESCRIPTION & VALUES \\
\hline 1. & Maximum BM & $-96.266 \mathrm{kNm}$ \\
\hline
\end{tabular}

\begin{tabular}{||l|l|l||}
\hline 2 & Maximum SF & $52.810 \mathrm{kN}$ \\
\hline 3 & Maximum Deflection & $2.90 \mathrm{~mm}$ \\
\hline
\end{tabular}

CRITICAL BEAMS: The graphical variations of bending moments, shear forces, and deflections in critical beams of Building I and Building II using bar chart are shown in Fig. 13. The graph is plotted between the building type ( $\mathrm{x}$-axis) versus the maximum values of critical beams ( $y$-axis).

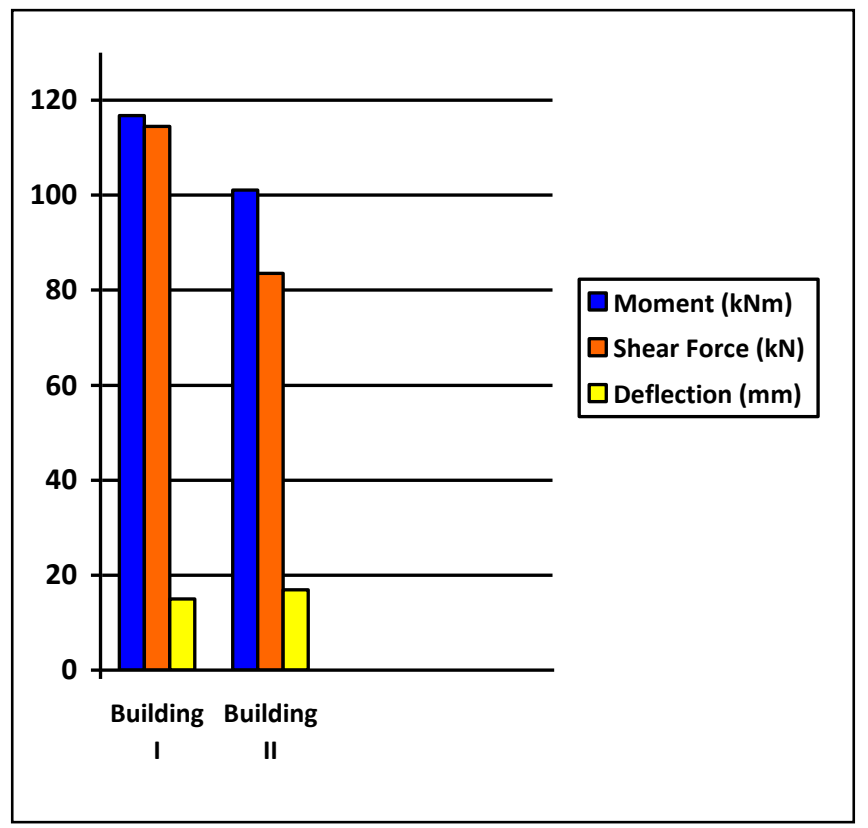

Fig. 13 Variation of Bending Moment, Shear Force, and Deflection of Critical Beams in Building I and Building II CRITICAL COLUMNS: The graphical variations of bending moments, shear forces, and deflections in critical columns of Building I and Building II using bar chart are shown in Fig 14. The graph is plotted between the building type (x-axis) versus the maximum values of critical columns (y-axis).
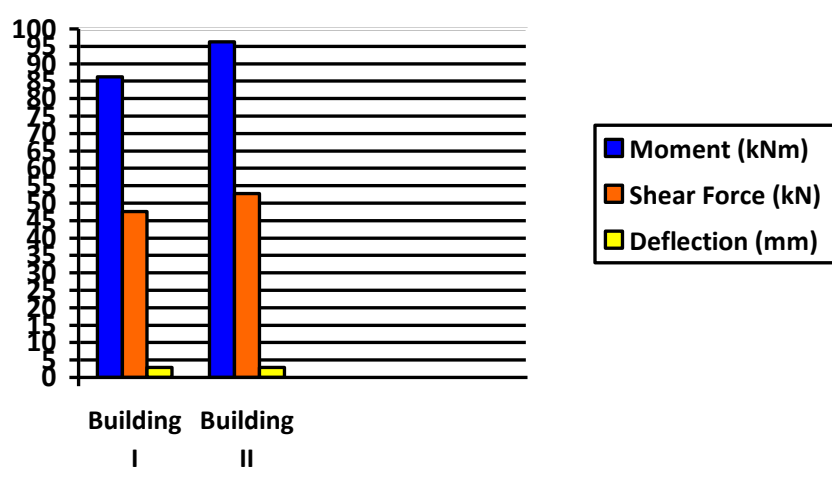

Fig. 14 Variation of Bending Moment, Shear Force, and Deflection in Critical Columns in Building $I$ and Building II

3D MODELLING: Edificius v.X(d), an ACCA BIM software has been used to execute the 3D Modelling and is further rendered in a rendering software named V-Ray ${ }^{[7]}$. The 3D-Modelling of Building I and Building II are shown in Fig. 15 and Fig. 16 respectively.

\section{Published By:}

Blue Eyes Intelligence Engineering and Sciences Publication

(c) Copyright: All rights reserved.

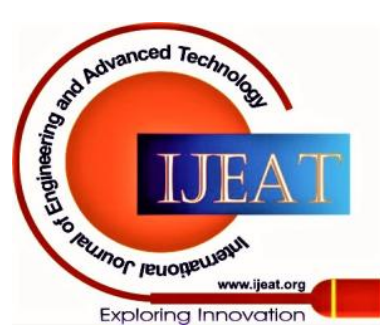




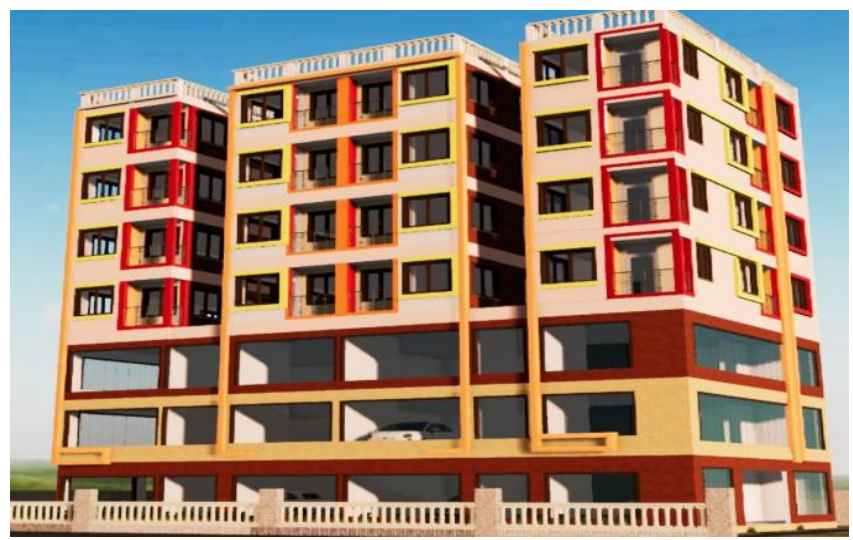

Fig. 15 3D-Modelling of Building I

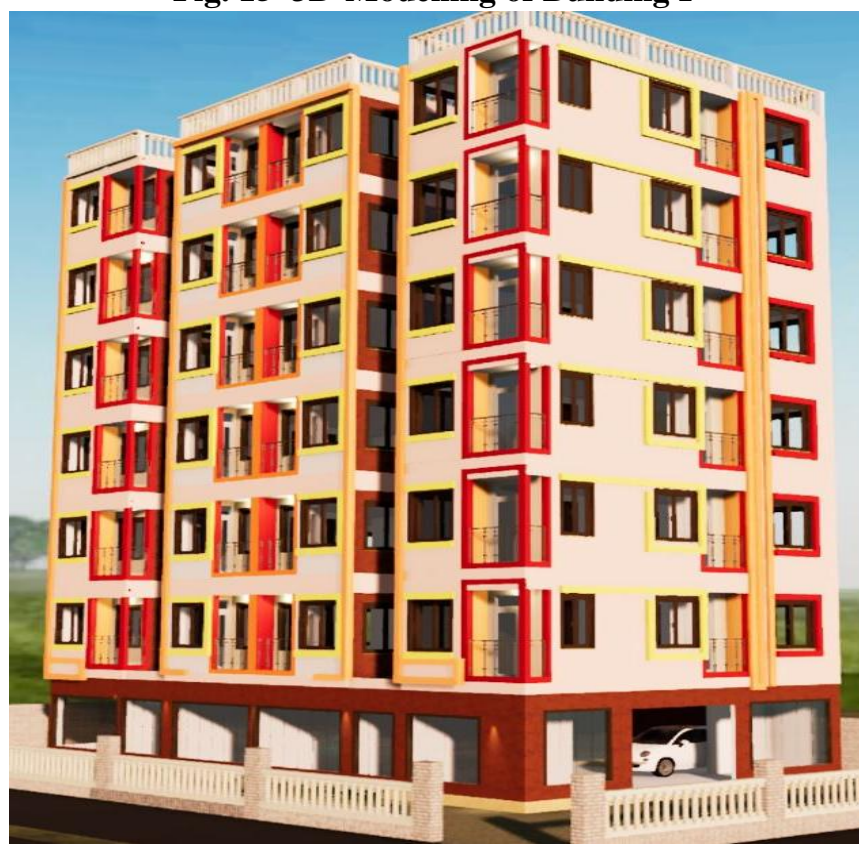

Fig. 16 3D-Modelling of Building II

\section{CONCLUSION}

To do the proper space management of the building a new type of planning is adopted in this project. Accordingly, different ideas are adopted from various references to achieve a remarkable building that will be economical, safe, and stable in terms of construction. The ramp and lift are used in the building for vertical transportation of cars from one floor to another. The building is planned in such a way so that it can provide maximum ventilation and reduces space management issues. The front setback of the building is considered as $6 \mathrm{~m}$ ${ }^{[8]}$. As per the Kolkata Municipal Corporation (KMC) and National Building Code (NBC) regulations, the permissible FAR is 3.0.The provided covered area is 3360 sq.m approx. which is less than the permissible covered area (3981.4 sq.m). Thus the proposed FAR is 2.5. If the permissible FAR of 3 is achieved in this land area, the total no. of floors of the building can be increased to G+7; one more floor can be constructed over each building. Thus the height of the floor will be increased to $23.2 \mathrm{~m}$ which is within the permissible height (46.5 m).

As per the analytical point of view,

- The deflection in columns is observed to be nearly the same for both the buildings and is within the permissible limit as per IS Code Books.

- Similarly, the deflection in beams is also observed to be nearly the same for both the buildings and is within the permissible limit as per IS Code Books.

- The moment in the column of Building I reduces by $11.6 \%$ when compared to the moment in the column of Building II.

- The moment in the beam of Building I increases by $15.5 \%$ when compared to the moment in the beam of Building II.

- The shear force in the column of Building I reduces by $11.1 \%$ when compared with the shear force in the column of Building II.

- The shear force in the beam of Building I increases by $37.0 \%$ when compared with the shear force in the beam of Building II.

\section{REFERENCES}

1. Sonila Sonker "Planning \& Designing of a Multi-Level Vehicle Parking at Aakash Ganga Shopping Complex Bhilai (Chhattisgarh)", Imperial Journal of Interdisciplinary Research (IJIR) , 2017, Vol-3, Issue-1, Page 1372-1387.

2. Aman, M Nalwadgi, et.al, "Analysis and Design of Multistorey Building by using STAAD Pro,” in IRJET, vol. 3, June 2016, pp. 887-891.

3. Abdul Qayyum, et. al, "Review of Multi-Storey Car Parking Building", International Research Journal of Engineering and Technology (IRJET), 2017, Vol- 04, Issue: 04, Page 2188 -2191.

4. Ravi Kumar B, Saleem SK “Analysis And Design OF Multi Storyed Building By Using STAAD PRO” Anveshana's International Journal Research in Engineering and Applied Sciences (AIJREAS), 2017, -Vol-2 Issue 01, Page 121-126.

5. T. Sasidhar, T.B. Manideep, I. Siva Kishore, N. Sanjana, "Analysis and Design of a high rise building $(\mathrm{G}+10)$ by STAAD Pro," in IJCIET, vol. 8, April 2017, pp. 654-658.

6. Pramod Kr, Venkatesh K, Pawan R, et.al "Analysis and design of multistoried parking building proposed at Jalahalli cross, Bengaluru," in IRJET, vol. 5, June 2018, pp. 1019-1024.

7. A L Kheyfets, V N Vasilieva, “ $3 \mathrm{D}$ Modeling as Modeling as Method for Construction and Analysis of Graphic Objects", IOP Conference Series: Material Science and Engineering (MSE), 2017, pp. 1-6.

8. IS SP 7: 2016, Code of National Building Code of India 2016 (Vol- 1), BIS, New Delhi.

\section{AUTHOR PROFILE}

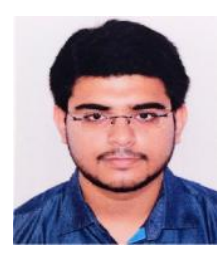

Sayan Ghar, pursuing MBA (Strategy and Leadership) from Liverpool Business School, United Kingdom (UK). He has completed his B.Tech (Civil Engineering) from SRM Institute of Science and Technology (SRM IST), Kattankulathur, Tamil Nadu, India. He has also been awarded with Merit-based Scholarship for 3 consecutive years by SRM Institute of Science and Technology (SRM IST). He was awarded Chartered Engineer (C.Eng) by the Institute of Engineers of India (IEI) and currently an Associate Member (AMIE) of IEI. He is also an Affiliated Member (Aff.M.ASCE) of the American Society of Civil Engineers (ASCE).

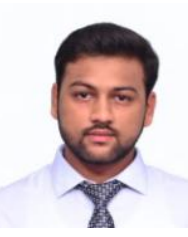

Kushal Jain, working as a designer and site engineer in a reputed construction company in Chhattisgarh, India. He has completed his B.Tech (Civil Engineering) from SRM Institute of Science and Technology (SRM IST), Kattankulathur, Tamil Nadu, India. He is a member of the American Society of Civil Engineers (ASCE).

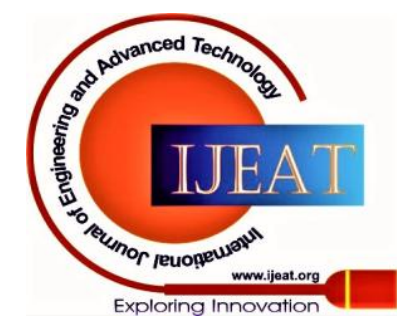

